\title{
PENGARUH MODEL PEMBELAJARAN KOOPERATIF STAD BERBASIS MULTI MEDIA INTERAKTIF TERHADAP PENGUASAAN KONSEP SISWA PADA MATERI TERMODINAMIKA
}

\author{
Jamuri $^{1}$, Kosim $^{2}$, Aris Doyan ${ }^{2}$ \\ Program Studi Magister Pendidikan IPA Program Pascasarjana Universitas Mataram ${ }^{123}$ \\ SMAN 5 Mataram $^{1}$ \\ jamesntb@yahoo.com, kosimho@yahoo.com, arisdoyan@yahoo.co.id
}

\begin{abstract}
ABSTRAK
Penelitian ini bertujuan untuk: Mengetahui pengaruh penggunaan model pembelajaran kooperatif tipe STAD berbasis multimedia interaktif terhadap Penguasaan konsep siswa pada materi termodinamika. Jenis penelitian yang dilakukan adalah penelitian eksperimen pretest-posttest control group design. Populasi penelitian adalah siswa kelas XI IPA di SMAN 5 Mataram. Sampel yang terpilih adalah dua kelas yang diambil secara simple random sampling yang berjumlah 73 siswa dengan rincian 37 siswa kelas eksperimen dan 36 siswa kelas kontrol. Data penelitian diambil melaui pemberian pretest dan posttest menggunakan soal kemampuan pemecahan masalah siswa terhadap kelas eksperimen dan kelas kontrol. Data yang diperoleh dianalisis menggunakan analisis $N$-gain untuk mengetahui prosentase peningkatan kemampuan pemecahan masalh siswa pada masingmasing kelas dan analisis ANAVA untuk mengetahui pengaruh model pembelajaran kooperatif STAD berbasis multimedia interaktif terhadap penguasaan konsep siswa pada materi termodinamika. Hasil analisis $N$-gain menunjukkan nilai mencapai $70 \%$ pada kelas ekperimen yang menunjukkan peningkatan penguasaan konsep siswa dan bearada pada kategori tinggi, sedangkan untuk kelas kontrol peningkatan penguasaan konsep siswa mencapaian nilai $50 \%$ yang berada pada kategori sedang. Analisis ANAVA pada taraf signifikansi $5 \%$ menunjukkan nilai signifikansi yang dihasilkan $0,000<0,05$ dari taraf signifikansi yang digunakan. Berdasarkan hasil analisis ANAVA diperoleh kesimpulan bahwa penggunaan model pembelajaran kooperatif tipe STAD berbasis multimedia interaktif dalam pembelajaran Termodinamika berpengaruh terhadap penguasaan konsep siswa.
\end{abstract}

Kata Kunci: Pembelajaran kooperatif, multimedia pembelajaran interaktif, penguasaan konsep.

\begin{abstract}
The objective of this study is : To know The influence of learning cooperative STAD model based on interactive multi media toward the student's mastery concept of thermodynamics. Type of study done, is experimental research by pretest-post test control group design. Population study is XI grade of Science students in SMAN 5 Mataram. The sample was chosen two classes which taken 73 students with random sampling which consisted of 37 students for experiment and 36 students for control. In this research taken through pretest and posttest by using the ability of problem solving student test toward experiment class and control class. The data analyzed by using $N$ - gain to know the increase percentage of problem solving of student's ability in each class. And ANAVA analysis to know cooperative learning model of STAD type based on interactive multi media toward the mastery of student concept in thermodynamics. Analysis result of $N$-gain shows that value reaches $70 \%$ with high category in mastery of student concept in experiment class. Whereas, the mastery of student concept in control class reaches $50 \%$
\end{abstract}


with average category. ANAVA analysis in significant level 5\% shows significant score gotten $0,000<0,05$ from significant level used. Based on the result of ANAVA analysis could be concluded that the use of cooperative learning model of STAD type based on interactive multimedia in learning thermodynamics influence toward the student's mastery concept,

Keywords: Learning Cooperative, Interactive Multi Media learning, Mastery Concept and problem solving ability

\section{PENDAHULUAN}

Materi subyek termodinamika merupakan salah satu materi fisika yang banyak memiliki konsep-konsep abstrak, sulit untuk divisualisasikan dan memiliki kompleksitas yang cukup tinggi. Biasanya, pembelajaran ini dilakukan secara konvensional yakni mengembangkan model matematika abstraks dan prinsip fisika dengan grafik dua dimensi dan teks saja, kemudian menggunakannya untuk memecahkan suatu permasalahan secara praktis. Model pembelajaran ini dapat mengakibatkan suatu situasi dimana siswa tidak dapat menerapkan teori yang telah dipelajarinya ke dalam situasi nyata, atau tidak dapat menjelaskan dengan pengetahuan yang telah diperolehnya.

Pembelajaran konsep fisika yang abstrak cenderung sulit dilakukan oleh guru, sehingga umumnya hasil belajar fisika pada materi abstrak lebih rendah dibandingkan pada materi yang konkrit. Salah satu alternatif yang bisa digunakan mendukung pembelajaran konsep-konsep abstrak yaitu penggunaan teknologi komputer dalam pembelajarannya. Teknologi komputer adalah sebuah penemuan yang memungkinkan menghadirkan beberapa atau semua bentuk interaksi sehingga pembelajaran akan lebih optimal. Konsepkonsep fisika tersebut direalisasikan dalam program komputer dengan menggunakan piranti lunak yang mudah dipelajari (Gunawan, 2008). Sejumlah bentuk interaksi dapat dimunculkan melalui media komputer seperti penyajian praktik dan latihan, tutorial, permainan, simulasi, penemuan, dan pemecahan masalah.

Para peneliti menemukan bahwa ada berbagai cara siswa dalam memproses informasi yang bersifat unik. Sebagian lebih mudah memproses informasi visual, sebagian lain lebih mudah kalau ada suara (auditorial), dan sebagian lain akan memahami dengan mudah atau lebih baik jika melakukannya dengan praktek. (Bobby, 1999).

\section{Pembelajaran Kooperatif Tipe STAD}

Belajar kooperatif (cooperatif learning) mengandung pengertian sebagai suatu pembelajaran yang menggunakan grup kecil dimana siswa bekerjasama belajar satu sama 
lain, berdiskusi dan saling berbagi ilmu pengetahuan, saling berkomunikasi, saling membantu untuk memahami materi pelajaran. Belajar kooperatif mempunyai pengertian lebih luas dari hanya sekedar kerja kelompok. Di dalam belajar kooperatif setiap anggota kelompok bertanggung jawab terhadap keberhasilan anggota-anggota kelompoknya dalam mencapai tujuan pembelajaran. Pembelajaran kooperatif dikembangkan untuk setidaktidaknya tiga tujuan pembelajaran penting, yaitu hasil belajar akademik, penerimaan terhadap keragaman, dan pengembangan keterampilan sosial (Ibrahim, dkk, 2000).

Slavin (2009) mendefinisikan belajar kooperatif (Cooperatif Learning) sebagai suatu teknik pembelajaran dimana siswa bekerja dalam suatu kelompok yang heterogen yang beranggotakan 4-6 orang. Heterogenitas anggota kelompok dapat ditinjau dari jenis kelamin, etnis, prestasi akademik maupun status sosial.

Berdasarkan beberapa pengertian pembelajaran kooperatif tersebut di atas terlihat adanya pergeseran peran guru yang sentral kepada peran guru yang mengelola aktivitas belajar siswa melalui kerja sama kelompok di kelas. Untuk itu Ibrahim, dkk (2000) mengemukakan ciri-ciri metode pembelajaran kooperatif antara lain:

a. Siswa bekerja sama dalam kelompok secara kooperatif untuk menuntaskan materi belajamya.

b. Kelompok dibentuk dari siswa yang memiliki kemampuan tinggi, sedang dan rendah.

c. Bilamana mungkin anggota kelompok berasal dari ras, budaya suku dan jenis kelamin berbeda.

d. Penghargaan lebih berorientasi pada kelompok ketimbang individu.

Ciri-ciri tersebut menempatkan metode pembelajaran kooperatif ini unik, karena selain membantu siswa memahami materi pelajaran juga melatih kemampuan siswa dalarn kerja sama kelompok.

Dalam model pembelajaran kooperatif, diberikan beberapa jenis pendekatan yang salah satunya Student Teams Achievmet Division (STAD). Pembelajaran kooperatif tipe STAD merupakan pendekatan yang dikembangkan untuk melibatkan siswa dalam menelaah materi yang tercakup dalam suatu pelajaran. Pada STAD siswa dalam suatu kelas tertentu dibagi menjadi kelompok dengan 4-5 orang, dan setiap kelompok haruslah heterogen yang terdiri dua laki-laki dan perempuan, berasal dan berbagai suku, memiliki kemampuan tinggi, sedang dan anggota tim menggunakan lembar kegiatan atau perangkat pembelajaran yang lain untuk menuntaskan materi pelajarannya, dan kemudian saling 
membantu satu sama lain untuk memahami bahan pelajaran melalui tutorial, kuis, satu sama lain dan melakukan diskusi.

Metode diskusi yang digunakan dalam pembelajaran kooperatif tipe STAD ini dengan ceramah, tanya jawab, diskusi, dan sebagainya, yang disesuaikan dengan kebutuhan dan kemampuan siswa. Menurut Slavin ada 5 langkah ulama di dalam pembelajaran yang menggunakan model STAD, yaitu (1) Penyajian Kelas (2) Tahapan Kegiatan Belajar Kelompok (3)Tahapan Menguji Kinerja Individu (4) Penskoran Peningkatan Individu, dan (5) Tahapan Mengukur Kinerja Kelompok.

\section{Multimedia Pembelajaran}

Perkembangan di bidang teknologi informasi memberikan pengaruh yang cukup besar bagi dunia pendidikan, khususnya dalam proses pembelajaran. Menurut Rosenberg (Gunawan, 2011) terdapat lima pergeseran dalam proses pembelajaran dengan berkembangnya penggunaan teknologi informasi yaitu, (1) dari pelatihan ke penampilan, (2) dari ruang kelas ke di mana dan kapan saja, (3) dari kertas ke "online" atau saluran, (4) dari fasilitas fisik ke fasilitas jaringan kerja, (5) dari waktu siklus ke waktu nyata.

Media dapat didefinisikan sebagai segala alat fisik yang menyajikan pesan yang merangsang, yang sesuai untuk belajar, misalnya media cetak, dan media elektronik. Media juga dapat didefinisikan sebagai komponen sumber belajar yang dapat merangsang siswa untuk belajar. Media pembelajaran adalah segala alat fisik yang berfungsi sebagai perantara baik berupa alat-alat elektronik, gambar, alat peraga, buku, dan lain-lain yang digunakan untuk menyampaikan pesan atau informasi dalam kegiatan pembelajaran.

Multimedia pembelajaran dapat diartikan sebagai aplikasi multimedia yang digunakan dalam proses pembelajran, dengan kata lain untuk menyalurkan pesan (pengetahuan, keterampilan dan sikap) serta dapat merangsang pilihan, perasaan, perhatian dan kemauan siswa sehingga secara sengaja proses belajar terjadi, bertujuan dan terkendali. Multimedia pembelajaran mempunyai pengertian penggunaan banyak media (teks, grafis, gambar, foto, audio, animasi dan video) atau paling tidak bermakna lebih dari satu media, yang digunakan untuk menyampaikan materi pembelajaran secara bersama-sama guna mencapai suatu tujuan pembelajaran tertentu.

Fungsi media pembelajaran dalam kegiatan pembelajaran bukanlah sekedar peraga bagi guru melainkan pembawa informasi atau pesan pembelajaran yang dibutuhkan siswa. Dengan demikian tugas guru dapat lebih terpusat pada bimbingan dan penyuluhan 
individual dan pengelolaan pembelajaran. Fungsi media pembelajaran menurut Derek Rountree (dalam Ahmad Rohani 1997) adalah: (1) membangkitkan motivasi belajar; (2) mengulang apa yang telah dipelajari; (3) menyediakan stimulus belajar; (4) mengaktifkan respon siswa; (5) memberikan balikan dengan segera; (6) menggalakkan latihan dengan serasi.

\section{Penguasaan Konsep}

Konsep merupakan gambaran mental dari gejala alam yang mempunyai lingkup yang luas mengenai keteraturan kejadian atau obyek, yang dinyatakan dalam suatu label (Liliasari, 2002). Konsep adalah dasar bagi perkembangan mental yang lebih tinggi untuk merumuskan prinsip-prinsip dan generalisasi-generalisasi. Namun secara umum konsep adalah suatu abstraksi yang menggambarkan ciri-ciri umum sekelompok objek, peristiwa, atau fenomena lainnya. Konsep dalam fisika biasanya dinyatakan dalam bahasa simbolik. Simbol yang digunakan merupakan manipulasi dari satu atau lebih penalaran proses IPA yang tidak dapat dinyatakan dalam bahasa sehari-hari.

Dalam fisika siswa dituntut untuk dapat memahami konsep-konsep yang ada, pemahaman konsep yang tertanam pada siswa akan membantu dalam memahami dan menyelesaikan soal-soal, ataupun menyelesaikan permasalahan yang dihadapinya dalam kehidupan. Pemahaman konsep adalah cara memahami sesuatu yang sudah terpola dalam pikirannya yang diakses oleh simbol verbal atau tertulis. Seorang siswa dikatakan memahami konsep jika konsep tersebut sudah tersimpan dalam pikiran siswa berdasarkan pola-pola tertentu yang dibutuhkan untuk ditetapkan dalam pikiran mereka sendiri sebagai ciri dari kesan mental untuk membuat suatu contoh konsep dan membedakan contoh dari non contoh.

\section{Metode Penelitian}

Dalam penelitian ini, terdapat satu variabel bebas, yaitu metode pembelajaran yang terdiri dari dua faktor: pembelajaran kooperatif STAD berbantuan MMI dan pembelajaran kooperatif STAD tanpa bantuan MMI. Sedangkan variabel terikat yang diteliti adalah penguasaan konsep siswa.

Berdasarkan tujuan yang hendak dicapai yaitu untuk mengetahui pengaruh penggunaan model pembelajaran STAD berbasis multimedia interaktif dalam pembelajaran Termodinamika terhadap kemampuan pemecahan masalah siswa, maka penelitian ini 
menggunakan desain eksperimen pretest-posttest control group design. Tabel 1 menunjukkan desain penelitian, dimana $X$ adalah perlakuan model pembelajaran multimedia interaktif (MMI), Y adalah model pembelajaran Non MMI, dan O adalah pretes dan postes.

Tabel 1 Desain penelitian

\begin{tabular}{|c|c|c|c|}
\hline Kelas & Pretes & Perlakuan & Postes \\
\hline Eksperimen & $\mathrm{O}$ & $\mathrm{X}$ & $\mathrm{O}$ \\
\hline Kontrol & $\mathrm{O}$ & $\mathrm{Y}$ & $\mathrm{O}$ \\
\hline
\end{tabular}

Populasi penelitian adalah siswa kelas XI IPA di SMAN 5 Mataram. Sampel yang terpilih adalah dua kelas yang diambil secara simple random sampling yang berjumlah 73 siswa dengan rincian 37 siswa kelas eksperimen dan 36 siswa kelas kontrol. Data penelitian diambil melaui pemberian pretest dan posttest menggunakan soal kemampuan pemecahan masalah siswa terhadap kelas eksperimen dan kelas kontrol.

Instrumen yang digunakan dalam penelitian ini terdiri dari Rencana Pelaksanaan Pembelajaran (RPP), tes penguasaan konsep, dan tes pemecahan masalah angket, lembar observasi aktivitas siswa, lembar observasi guru. Data yang diperoleh dianalisis menggunakan analisis $N$-gain untuk mengetahui prosentase peningkatan kemampuan pemecahan masalh siswa pada masing-masing kelas dan uji statistik anakova SPSS versi 20 untuk mengetahui pengaruh model pembelajaran kooperatif STAD berbasis multimedia interaktif terhadap kemampuan pemecahan masalah pada materi termodinamika.

Untuk mengetahui peningkatan pengusaan konsep fisika siswa yang menggunakan multimedia interaktif, maka skor pretest dan skor posttest dari kelas ekperimen dan kelas kontrol dianalisis dengan menggunakan rumus N-gain (Hake, 1999 dalam Maharika, 2011) sebagai berikut:

$$
g=\frac{S_{p o s t}-S_{p r e}}{S_{\text {maks }}-S_{p r e}} \times 100 \%
$$

$$
\begin{aligned}
\operatorname{dimana}: \mathrm{g} & =\text { Gain } ; \\
\text { Spre } & =\text { Skor pretest; } \\
\text { Spost } & =\text { Skor posttest; dan } \\
\text { Smaks } & =\text { Skor maksimal ideal. }
\end{aligned}
$$

Keterangan: Kriteria tingkat Gain adalah seperti pada tabel di bawah ini.

Tabel 2 Kategori tingkat Gain 


\begin{tabular}{|c|c|}
\hline Batasan & Kategori \\
\hline $\mathrm{g}>0,7$ & Tinggi \\
\hline $0,3 \leq \mathrm{g} \geq 0,7$ & Sedang \\
\hline $\mathrm{g}<0,3$ & Rendah \\
\hline
\end{tabular}

\section{Hasil dan Pembahasan}

Multimedia interaktif (MMI) yang dibuat dengan menggunakan adobe flash. MMI ini didesain dapat digunakan dengan pembelajaran STAD dan mendukung peningkatan kemampuan pemecahan masalah siswa.

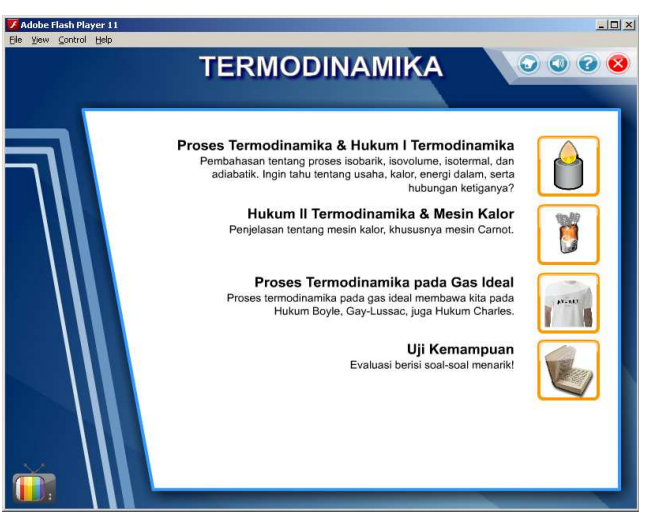

(a)

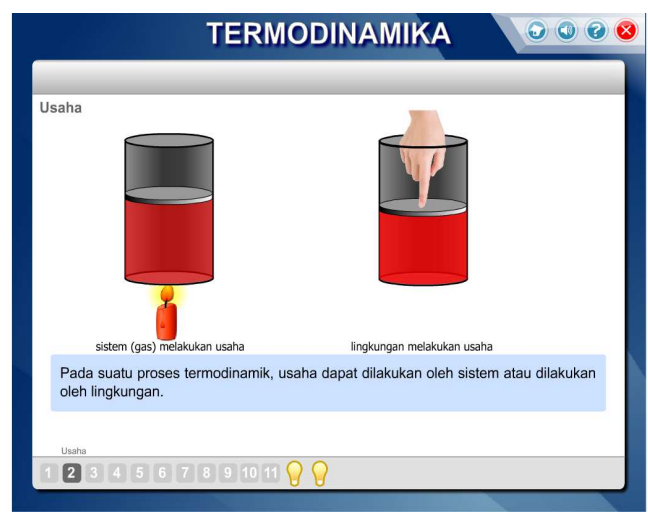

(b)

Gambar 1. (a) Tampilan utama MMI (b) Salah satu simulasi dalam MMI.

Tabel 3 MMI memiliki fitur-fitur berikut MMI yang dibuat:

\begin{tabular}{|c|c|c|}
\hline & Komponen Model & Penjelasan \\
\hline 1 & Menu Utama & $\begin{array}{l}\text { Terdiri empat menu, tiga menu tentang materi dan } \\
\text { satu menu uji kemampuan: } \\
\text { - Proses termodinamika dan Hukum I } \\
\text { Termodinamika. } \\
\text { - Hukum II Termodinamika dan mesin kalor. } \\
\text { - Proses termodinamika pada gas ideal } \\
\text { - } \quad \text { Uji kemampuan }\end{array}$ \\
\hline 2 & Menu Materi & $\begin{array}{l}\text { Tiga menu pertama pada menu utama adalah menu } \\
\text { materi. Setiap materi memiliki uraian materi yang } \\
\text { mengandung unsur animasi dan simulasi, serta } \\
\text { bagian khusus yang melatih kemampuan pemecahan } \\
\text { masalah siswa. } \\
\text { Pada latihan kemampuan pemecahan masalah, } \\
\text { terdapat lima submenu yang dapat diikuti oleh siswa: } \\
\text { - Memfokuskan masalah } \\
\text { - Menguraikan secara konsep fisika } \\
\text { - Merencanakan solusi }\end{array}$ \\
\hline
\end{tabular}




\begin{tabular}{|l|l|l|}
\hline \multicolumn{2}{|c|}{ Komponen Model } & \multicolumn{1}{c|}{ Penjelasan } \\
\hline & & - Melaksanakan rencana pemecahan masalah \\
& & Membeikan evaluasi pada solusi \\
\hline 3 & Uji Kemampuan & $\begin{array}{l}\text { Dapat digunakan siswa untuk evaluasi dan langsung } \\
\text { dapat melihat laporannya di akhir evaluasi. }\end{array}$ \\
\hline
\end{tabular}

Pelaksanaan penggunaan metode pembelajaran berbasis multimedia interaktif sebanyak enam kali tatap muka, tetapi sebelumnya kedua kelas diberikan soal pretest dengan soal penguasaan konsep untuk materi termodinamika sebanyak 32 soal dengan skor maksimal 32 dan setelah memperoleh perlakuan kedua kelas diberikan posttest dengan soal penguasaan konsep yang sama. Skor pretest dan skor posttest masing-masing kelas ditampilkan pada tabel berikut.

Tabel 4 Perolehan skor pada kelas kontrol dan kelas ekperimen
penguasaan konsep
\begin{tabular}{|l|c|c|c|c|}
\multicolumn{1}{|c}{ Perolehan } & Kelas Eksperimen & Kelas Kontrol \\
\cline { 2 - 5 } & Pretest & Postest & Pretest & Postest \\
\hline Skor maksimum & 87,5 & 96,88 & 68,75 & 87,5 \\
\hline Skor minimum & 43,75 & 65,63 & 25 & 56,25 \\
\hline Skor rata-rata & 65,04 & 90,12 & 47,4 & 71,79 \\
\hline
\end{tabular}

Dari tabel 4 terlihat adanya peningkatan skor penguasaan konsep siswa, dari skor pretest ke skor posttest siswa, baik pada kelas eksperimen maupun pada kelas kontrol. Untuk mengetahui kualitas peningkatan kemampuan pemecahan masalah dan hasil yang diperoleh digunakan analisis $\mathrm{N}$-gain berikut ini terlihat pada tabel 5 berikut:

Tabel 5 Hasil Analisis $\boldsymbol{N}$-gain kelas eksperimen dan kelas kontrol

\begin{tabular}{|c|c|c|c|c|}
\hline Sampel & $\begin{array}{c}\text { Rata-rata skor } \\
\text { Tes Awal }\end{array}$ & $\begin{array}{c}\text { Rata-rata skor } \\
\text { Tes Akhir }\end{array}$ & N-Gain & Kategori \\
\hline Kelas eksperimen & 65,04 & 90,12 & 0,7 & Tinggi \\
\hline Kelas kontrol & 47,4 & 71,79 & 0,5 & Sedang \\
\hline
\end{tabular}

Dari tabel 5 di atas terdapat kenaikan rata-rata kemampuan pemecahan masalah baik untuk kelas kontrol maupun untuk kelas eksperimen. Besar kenaikan rata-rata untuk kelas eksperimen dengan N-Gain 0,7 termasuk kategori tinggi, sedangkan untuk kelas kontrol besar kenaikan rata-ratanya dengan $\mathrm{N}$-Gain 0,5 termasuk kategori sedang, kenaikan rata-rata kelas eksperimen lebih baik bila dibandingkan dengan kelas kontrol. Perbedaan kenaikan rata-rata ini karena adanya perlakuan yang berbeda antara kelas kontrol dengan kelas eksperimen. Jika dibuatkan histogramnya terlihat pada gambar 2 sebagai berikut: 


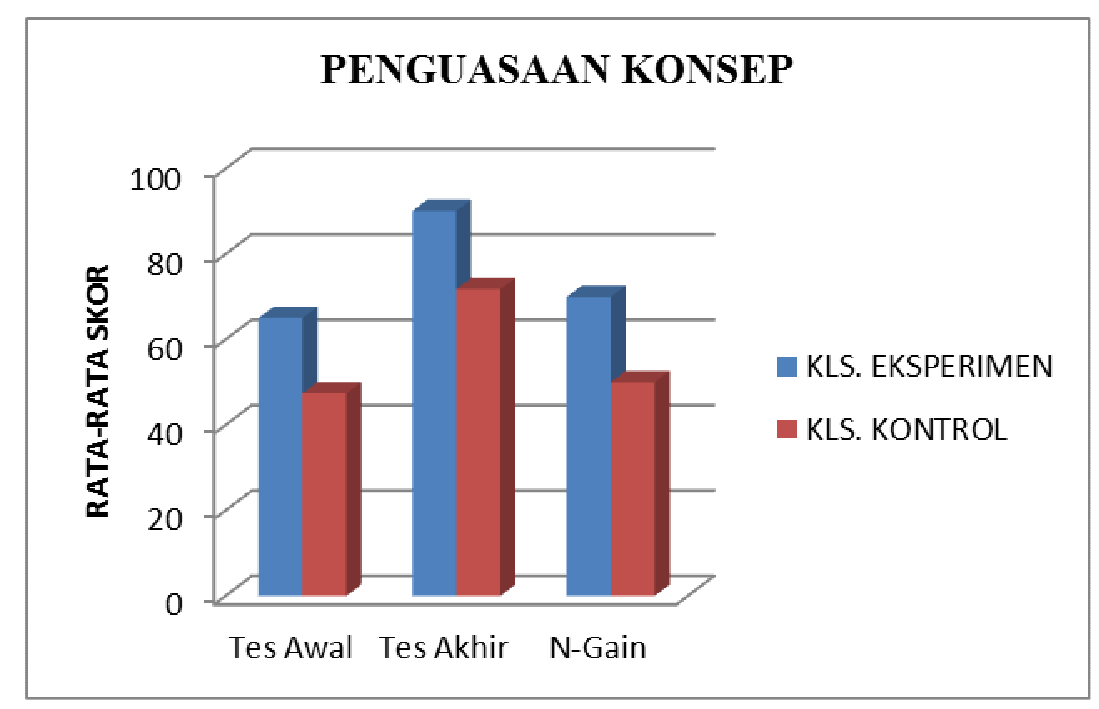

Gambar 2. Grafik rata-rata skor tes awal, tes akhir, dan N-Gain Penguasaan Konsep

Data capaian skor yang tercantum dalam tabel 5 di atas, selanjutnya dilakukan uji parasyarat yaitu uji normalitas distribusi data. Rekapitulasi dan uji homogenitas vairians pada taraf signifikansi 5\%. Hasil uji normalitas dengan Kolmogorov-Smirnov dan ShapiroWilk berbantuan SPSS 20 dapat dilihat pada Tabel 6 berikut:

Tabel 6 Hasil Uji Normalitas Data Penguasaan Konsep Siswa

\begin{tabular}{|c|r|r|r|r|r|r|}
\hline \multirow{2}{*}{ METODE } & \multicolumn{3}{|c|}{ Kolmogorov-Smirnov $^{\mathrm{a}}$} & \multicolumn{3}{c|}{ Shapiro-Wilk } \\
\cline { 2 - 7 } & Statistic & \multicolumn{1}{c|}{ Df } & \multicolumn{1}{c|}{ Sig. } & Statistic & \multicolumn{1}{c|}{ Df } & \multicolumn{1}{c|}{ Sig. } \\
\hline Eksperimen & .169 & 36 & .072 & .937 & 36 & .072 \\
\hline Kontrol & .147 & 37 & .086 & .826 & 37 & .064 \\
\hline
\end{tabular}

Dari tabel 6 tersebut, dapat dilihat bahwa signifikansi kelas eksperimen dan kelas kontrol untuk uji Kolmogorov-Smirnov masing-masing memiliki nilai yang sama yaitu 0.061 dan 0,072. Nilai signifikansi ini lebih besar dari taraf signifikansi yang digunakan, yaitu 0.05. Demikian pula halnya dengan uji Shapiro-Wilk, nilai signifikansi yang dihasilkan untuk kelas eksperimen 0.086 dan signifikansi kelas kontrol adalah 0.064. Kedua nilai signifikansi yang dihasilkan ini lebih besar dari signifikansi yang digunakan yaitu 0.05. Dengan demikian, dapat disimpulkan bahwa untuk kelas eksperimen dan kelas kontrol berasal dari populasi terdistribusi normal.

Untuk uji homogenitas acuan yang digunakan untuk menentukan, apakah sampel memiliki varian yang sama atau tidak yaitu, bila nilai signifikansi hasil hitung lebih besar dari taraf signifikansi yang digunakan $(\alpha=0,05)$ maka sampel memiliki varian yang sama 
atau homogen, dan bila sebaliknya maka sampel memiliki varian yang tidak sama atau tidak homogen. Untuk mendapatkan data tersebut peneliti menggunakan Uji homogenitas dengan uji Levene berbantuan SPSS 20. Berikut adalah output SPSS untuk uji tersebut:

Tabel 7 Hasil Uji Homogenitas Data Penguasaan Konsep Siswa

\begin{tabular}{|c|c|c|c|}
\hline $\mathrm{F}$ & $\mathrm{df} 1$ & $\mathrm{df} 2$ & Sig. \\
\hline .044 & 1 & 71 & .834 \\
\hline
\end{tabular}

Pada tabel 7 terlihat bahwa signifikansi homogenitas yang dihasilkan yaitu 0.201. Karena nilai signifikansi $0.834>0.05$, maka dapat disimpulkan bahwa kedua kelas memiliki varian yang sama atau homogen.

Uji hipotesis menggunakan analisis anakova dapat dilakukan karena telah memenuhi syarat, yaitu data berasal dari sumber yang homogen dan data terdistribusi secara normal. Hasil uji ANAKOVA dengan menggunakan SPSS versi 20 terlihat pada tabel 8 sebagai berikut:

Tabel 8 Hasil Uji ANAKOVA

\begin{tabular}{|c|r|l|l|l|l|l|}
\hline Source & $\begin{array}{l}\text { Type III Sum } \\
\text { of Squares }\end{array}$ & \multicolumn{1}{c|}{ Df } & Mean Square & F & Sig. \\
\hline MMI & 323.552 & 1 & 323.552 & 49.663 & .000 \\
\hline
\end{tabular}

Dari di atas maka menurut hasil uji hipotesis pada taraf signifikansi 0,05 ini menunjukkan bahwa model pembelajaran kooperatif tipe STAD berbasis multimedia interaktif yang digunakan mempengaruhi kemampuan siswa dalam mengintegrasikan beberapa pemahaman ke dalam kerangka berpikir siswa dalam memahami dan menyelesaiakan masalah.

Pada proses pembelajaranya siswa dalam melaksanakan diskusi informasi menggunakan bantuan multimedia interaktif (MMI), dimana antara media pembelajaran dengan siswa terjadi interaksi. bahan ajar dan sumber belajarnya adalah pengetahuan yang dimiliki, bahan ajar cetak dan media belajar yang interaktif yang dihadapinya serta penjelasan dari guru. Dari pengamatan di lapangan siswa lebih aktif dan memiliki rasa ingin tahu yang mendalam dalam melaksanakan diskusi informasi baik sesama teman satu kelompok maupun dengan teman-teman dari kelompok lainnya sehingga dalam bereksplorasi dan mencari solusi sesuai dengan harapan dan hasil yang didapat lebih baik bila dibandingkan dengan temen-teman pada kelas kontrol yang tanpa menggunakan multimedia interaktif dalam pembelajarannya. 
Ada pengaruh positif yang luar biasa yang tertanam pada diri siswa untuk mencari tahu dan ingin tahu lebih dalam mengenai materi yang didiskusikan, hal ini terjadi penggunaan multimedia interaktif (MMI) dalam pembelajaran fisika lebih menyenangkan, lebih konkrit dan nyata, lebih mudah menggali dan mengungkap materi ajar yang didiskusikan. Secara umum terdapat perbedaan yang signifikan antara kelas eksperimen dan kelas kontrol, dimana pemaham konsep kelas eksperimen lebih tinggi dibandingkan kelas kontrol. Perbedaan penguasaan konsep ini disebabkan karena perbedaan penyajian materi yang diberikan. Materi dengan model pembelajaran kooperatif berbasis multimedia disajikan dengan lebih menarik dan interaktif. Siswa mengkonstruksi konsep pembelajarannya sendiri dengan dukungan dari teman kelompok

\section{Kesimpulan}

Berdasarkan data yang dikumpulkan dan hasil dari analisis data yang telah dikemukakan dapat disimpulkan bahwa terdapat pengaruh penggunaan model pembelajaran kooperatif berbasis multimedia interaktif dalam pembelajaran Termodinamika terhadap penguasaan konsep siswa.

\section{Daftar Pustaka}

Bobby, D. (1999). Quantum Learning. Jakarta: Kaifa

Borg, W. \& Gall, M.D. 1983. Educational Research; An Introduction. 4th Edition. New York: Longman Inc.

Dahar, R.W. (1996). Teori-Teori Belajar. Jakarta: Erlangga.

Gunawan. (2008). Model Pembelajaran Berbasis Multimedia Interaktif Untuk Meningkatkan Penguasaan Konsep Calon Guru Pada Materi Elastisitas. Jurnal Penelitian Pendidikan IPA. Vol. 2 No. 1, $11-21$.

Gunawan. (2011). "Model Multimedia Interaktif Elastisitas dan Implikasinya Terhadap Peningkatan Penguasaan Konsep dan Keterampilan Berpikir Kritis Mahasiswa". Jurnal Kependidikan IKIP Mataram. Vol 10 (1) 29 - 37

Huffman, D. (1997). Effect of explicit problem solving instruction on high school students' problem-solving performance and conceptual understanding of physics. Journal of Research In Science Teaching Vol. 34, No. 6, Pp. 551-570 (1997).

Ibrahim, M dan Nur, M. (2000). Pengajaran Berdasarkan Masalah. Surabaya: University Press. 
Liliasari, (2002). Pengembangan Model Pembelajaran Kimia Untuk Meningkatkan Strategi Kognitif Mahasiswa Calon Guru Dalam Menerapkan Berpikir Konseptual Tingkat Tinggi. Laporan Penelitian Hibah Bersaing IX Perguruan Tinggi Tahun Anggaran 2001-2002. Bandung: FPMIPA UPI.

Mahardika. 2011. Pengembangan Bahan Ajar Mekanika untuk Meningkatkan Kemampuan Representasi Verbal, Matematis, Gambar, dan Grafik Mahasiswa Calon Guru Fisika. Disertasi. Bandung: Disertasi PPS UPI

Osarizalsyam. (2006). Penerapan Model Pembelajaran Kooperatif Tipe Two Stay Two Stray pada Konsep Komponen Ekosistem, Peran, dan Interaksinya untuk Meningkatkan Kemampuan Pemecahan Masalah Siswa SMP. Tesis PPs UPI Bandung: Tidak diterbitkan.

Rohani Ahmad. (1997). Media Instruksional Edukatif. Jakarta: Rineka Cipta.

Slavin, R.E. (2009). Cooperatif Learning. Bandung : Nusa Media 